to 1,287 , the latter figure including 472 professional, 552 technical, 182 clerical and 81 others.

The Director-General, directing attention to the applied resoarch which constitutes most of the Department's work, notes that the experimental measures for controlling yellow dwarf virus disease of barley are estimated to have

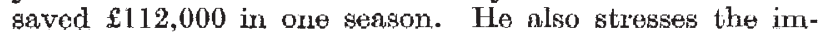
portance of the fundamental research on which this applied research is based, instancing the discoverios of the Fruit Research Division relating to plant cell division and the advancos in understanding of wood shrinkage and aurora made by the Dominion Physical Laboratory. In a geochemical laboratory of the Geological Survey and University of Otago investigations at high tomperatures and pressures have shown that greywackes and argillites constituting many New Zealand mountain ranges lose their chlorite minerals and begin to grow other platy minorals like mica when heated bolow their melting point at pressures up to 1,000 atmospheres, and the growth of the platy minerals can be oriented in one plane to givo schistosity similar to that in large areas of Otago rocks. Laboratory rosearch has also shown that temperature is the most important factor in the conversion of lignite into biturninous conl.

Sheep grazing trials in the Manawatu on New Zealand short-rotation and on Ariki and Italian ryegrass indicate that cellulose content is an important controlling factor in the nutritive quality of ryograss. The Grasslands Division has demonstrated the practicability of highstocking rates on steep hill country at $\mathrm{Te}$ Awa and has found that heavier stocking rates may limit the useful life of ewes by increasing the wear on the sheep's teeth. Movements of mineral constituents through the soil have been demonstrated by the use of radioisotopes, and recent work at the Soil Buroau has shown that severo iron deficiency in Crotalaria, a tropical legume used as a green manure crop, can be corrected by use of iron chelate, which is stable under alkaline conditions. Rabbit population investigations have emphasized the importance of natural predators of rabbits in control in the wild, and fiold experiments have confirmed the wide existence of grass-grub populations tolerant to DDT. A new crownrust resistant strain of 'Onward' oat has been bred by the Crop Research Division and released as 'Onward (1963)", and the Division is also testing potato hybrids for processing for export. The Fruit Research Division has now succeeded in isolating from immature sweet corn seeds a natural cell-division stimulant, or kinin, which has been named 'Zeatin', and its synthesis is now being attempted.

Systematic astrolabe observations were recommenced in January 1964, and the Dominion Physical Laboratory has shown that very low-frequency signals travelling over long distances can sometimes suffer such severe phase distortion as to render them useless for navigational purposos. A small-scale process for steol castings has bcon further simplified by using a charge composed almost entirely of steel scrap and adding silica and manganese as ferro-alloys to produce the heat of reaction. The economics of the process are satisfactory and it now has possibilities for the average New Zealand foundry.

The main programme of geothermal investigation at Ngawha has been completed, but prospects of useful resources within economic depths do not appear hopeful. In investigations of the optimum sulphate contont of cements a method has been developed for dotermining the degree of dehydration of gypsum, and the Wheat Research Institute, from theoretical investigations of the loss of steam from bakers' ovens and the devolopment of an instrument for rapidly moasuring the concentration of steam in the oven, has dovised important designs for bakers' ovens and a number of travelling ovens have been built to this dosign. Roports from the various branches are included in the report, to which lists of publications during the year are appended. The sixth annual report of the Ross Depondency Research Com. mittee is also appended, as well as brief reports on grantaided research in the Cawthron Institute, Lincoln College, Massoy University College of Manawatu, and the University of Canterbury.

\title{
SCIENTIFIC POLICY IN BELGIUM
}

THE Inventaire du Potentiel Scientifique de la Belqique -Année 1961, issued by the National Council for Scientific Poliey (Pp. 303. Brussols, 1964) is in three parts. The first scts forth the reasons for the survey, its principal characteristics and the methods used. The socond, which occupies roughly one-half of the report, contains the statistical information and appondixes, while a third part, occupying about one-third of the whole, lists the units participating in the survey. The survey estimates the number of effective full-time porsonnel in 1961 as 22,504 engaged in 1,644 scientific units, and of these 6,703 were of university status, 2,451 held higher technical diplomas and 13,350 wero technicians, craftsmen and others. Excluding those in the sector of teaching, intor-university centres and learned societies, the expenditure of these units was about 4,312.9 million francs. Of these 1,644 units, 1,284 were concernod with the exact sciences ( 628 with technology) and 180 with the social sciences, and another $180 \mathrm{with}$ the other research sciences; the numbers of those with a university degree thus occupied are 5,433, 821 and 448, respectively. Again, in 81.5 per cent of those in the field of education, 71.6 per cent of those in the public sector, 55.7 per cent of those in private industry, 61.4 per cent of industrial or agricultural rescarch associations, 50 per cent of other private establishments and in all the inter-university centres research is an important activity, the percentage of university graduates engaged in such activities being estimated at $85 \cdot 5,73 \cdot 9,86 \cdot 6,71,56 \cdot 3$ and 100 , respectively.
The four universities employed 80 por cent of the scientific units and 88 per cent of the personnol with university qualifications in the educational sector; 56 per cent of the latter was in the faculties of science and medicine. Ministerial departments included 64 per cent of the scientific units and 59 per cent of university graduates in the public sector, 45 per cent of the latter being employed in the Ministrios of Education, Agriculture and Defence. Although private enterprise and tho industrial and agricultural research associations only include 16 per cent of the scientific units, thoy include 58 per cent of university graduates engaged in research in this sector, 17 per cent of these being in the research associations. Firms with more than 1,000 employees with research departments numbercd only 10 per cent of firms engaged in such activitics and employed 49 por cent of the university graduates in this sector.

Nearly half the scientific units and more than half the university graduates engaged in such activities aro employed in the province of Brabant, those of Liège and Last Flanders coming next with 15 per cent each, mainly in the educational sector in East Flanders. In the exact sciences, mathematics accounts for 54 per cent of the units and 62 per cont of the personnel. Those engaged in technology employed 20 per cent of university graduates engaged in scientific work in industry, but in the educational field only 14 por cent of the scientific units and 14 per cent of university graduates were concerned with technology. In the exact sciences 25.9 per 
cent of units and $33 \cdot 7$ per cent of personnel were engaged exclusively or mainly in fundamental research, compared with $62 \cdot 1$ per cent and $54 \cdot 1$ per cent, respectively, for applied research.

Nearly 10 per cent of the scientific units employed no persons with university qualifications and nearly 90 per cent of the units employed not more than 10, while about a quarter had no technicians or trained auxiliaries. Some 60 per cent employed no one with technical diplomas and nearly half the remainder employed only one such person. In the educational sector, 24 units employed some 15 per cent of the university graduates, mainly in the faculties of science and medicine, while in the public sector 13 per cent were employed in 3 per cent of the units in this sector, especially at the Centre for the Study of Nuclear Energy. Excluding the educational sector in the exact sciences, about half the units spent less than 1 million francs on research in 1961, and half these not more than 700,000 francs. In the public sector, including research associations, half the units spent not more than 3 to 4 million francs, while ten private enterprises, responsible for 60 per cent of the expenditure on such activities by private enterprise, spent more than 50 million franes and 5 of those 100 million franes.

\section{REGIONAL ADMINISTRATION IN FRANCE}

\begin{abstract}
A
PAMPHLET, The French Administrative Reform, issued by the Press and Information Service of the French Embassy, describes the structures of the Departments, of the Paris region, and of the other Regions as modernized by the decrees of March 14, 1964 (Pp. 30. London: Ambassade de France, Service de Presse et d'Information, 1964). The reforms, which will be implemented over a period extending to at least 1965, are based on the results of experiments conducted during two years in five test departments and in the pilot regions of Upper Normandy and Burgundy. The basic principle consists in making the Prefect once more solely responsible for the State service; the sole representative of the Government in the Department, he is the sole co-ordinator of public activities, with the exception of the military services, judicial services, assessment and collection of taxes, payment of public expenses, valuation of national property, factory inspection and supervision of the application of the social loans in agriculture. To ensure that the Prefect is fully informed of all important aspects of life in his Department, a central correspondence service will provide photographic copies of incoming letters, while copies of outgoing letters will also be submitted. Delegation of power is provided for certain highly technical services but delegation of signature allows more freedom and flexibility to heads of services.

A similar principle has been applied to the regions but only to external services concerned with economic matters, public investment and equipment, those which manage Government stocks or participate in programmes
\end{abstract}

involving national public funds. Such State services in the regions will be placed directly under the Prefect of the Region and cease to be directly under the Paris ministries. The Prefect will accordingly now have a role of initiation and decision in the economic field and a simple function of co-ordination in the administrative field. He will be assisted by an enlarged inter-departmental administrative conference and by a new com. mission on regional economic development. The new commission will be consulted when the Government prepares future development plans, after the draft has been submitted to Parliament and again after the final planning project has been discussed by Parliament and the operative sections relating to each region have been defined.

This regional reform does not apply to the Paris region, the administrative districts of which are being subdivided to give smaller units while a single assembly will replace the General Council and the Municipal Council, retaining on the whole the powers of the present Municipal Council and assuming those possessed by the General Council of the Seine. The suburbs are to be divided into Departments of normal status, while the pilot prefectures will permit construction of national administrative cities in each chief town. Provision is also made for a system of administrative and economic co-ordination, including a regional assembly or council, the composition of which is not yet fixed. Additional financial resources will be provided and it is anticipated that the new organization should be functioning smoothly by 1968 .

\section{THE BUILDING RESEARCH STATION}

\begin{abstract}
A its headquarters in Bucknalls Lane, Garston, Watford, Herts., the Building Research Station (Department of Scientific and Industrial Research) had its 'Open Days, 1964' during September 22-25, when members of the public, including Press representatives, were accorded an unrivalled opportunity of seeing something of the inside workings of this long-established and important organization. Displays and hourly full-scale demonstrations illustrating some of the more important activities of the Station and many items of present-day research were made available to the visitors. In the department concerned with building operations and economics, the theme is research into the efficiency and economy of building operations, development of new techniques, examination of methods of management and organization, and factors influencing costs. Mechanical engineering deals with research applied to production and handling of building components on site and in the factory, and investigations in the engineering services requisite to completed buildings. Environmental physics is concerned both
\end{abstract}

with factors controlling conditions in buildings and with the subjective reactions of the occupants to these conditions. The section devoted to user requirements and design deals with building design and occupants' requirements in relation to housing and to some special building types. Research in the materials department ranges from the constitution and properties of building materials to investigation of their behaviour in use, including laboratory-scale tests to pilot plant trials. Structural engineering is concerned fundamentally with loadings, with the behaviour both of components and of full-scale and model structures, and with the engineering properties of building materials.

The soil mechanics department was the first to be set up in Britain. It has done pioneer work on the engineering properties of soils and their relationship to the structural behaviour of foundations, tunnels, retaining walls and earth dams. A section devoted to mathematics provides a service for the rest of the Station, and present-day work, reflecting projects in three other departments, includes the 